\title{
Correction to: A framework for teaching socio-environmental problem-solving
}

\author{
Cynthia A. Wei ${ }^{1,2} \cdot$ Michael L. Deaton ${ }^{3} \cdot$ Teresa J. Shume $^{4} \cdot$ Ramiro Berardo $^{5} \cdot$ William R. Burnside $^{1}$
}

Published online: 1 August 2020

(C) The Author(s) 2020

\section{Correction to: Journal of Environmental Studies and Sciences https://doi.org/10.1007/s13412-020-00603-y}

The article A framework for teaching socio-environmental problem-solving, written by Cynthia A. Wei, Michael L. Deaton, Teresa J. Shume, Ramiro Berardo and William R. Burnside was originally published electronically on the publisher's internet portal on 11 April 2020 without open access. With the author(s)' decision to opt for Open Choice the copyright of the article changed on July 2020 to (C) The Author(s) 2020 and the article is forthwith distributed under a Creative Commons Attribution 4.0 International License (https:// creativecommons.org/licenses/by/4.0/), which permits use, sharing, adaptation, distribution and reproduction in any medium or format, as long as you give appropriate credit to the original author(s) and the source, provide a link to the Creative Commons license, and indicate if changes were made. The original article has been corrected.

The online version of the original article can be found at https://oi.org/ $10.1007 /$ s $13412-020-00603-y$

\section{Cynthia A. Wei \\ Cynthia.Wei@georgetown.edu}

1 National Socio-Environmental Synthesis Center (SESYNC), 1 Park Place Suite 300, Annapolis, MD 21401, USA

2 Walsh School of Foreign Service, Georgetown University, 3700OSt. NW, Washington, DC 20057, USA

3 School of Integrated Sciences, James Madison University, MSC 4102, 701 Carrier Drive, Harrisonburg, VA 22807, USA

4 School of Education, North Dakota State University, Dept. 2625, PO Box 6050, Fargo, ND 58108, USA

5 School of Environment and Natural Resources, The Ohio State University, 316B Kottman Hall, Columbus, OH 43210, USA
Publisher's note Springer Nature remains neutral with regard to jurisdictional claims in published maps and institutional affiliations.

Open Access This article is licensed under a Creative Commons Attribution 4.0 International License, which permits use, sharing, adaptation, distribution and reproduction in any medium or format, as long as you give appropriate credit to the original author(s) and the source, provide a link to the Creative Commons licence, and indicate if changes were made. The images or other third party material in this article are included in the article's Creative Commons licence, unless indicated otherwise in a credit line to the material. If material is not included in the article's Creative Commons licence and your intended use is not permitted by statutory regulation or exceeds the permitted use, you will need to obtain permission directly from the copyright holder. To view a copy of this licence, visit http://creativecommons.org/licenses/by/4.0/. 